\title{
Synthesis, characterization and antimicrobial activity of some new dihydropyrano[c]chromenes
}

\author{
Ankita Bhalu ${ }^{1}$, Pooja Moteriya ${ }^{2}$, Sumitra Chanda ${ }^{2}$, Shipra Baluja ${ }^{1, *}$ \\ ${ }^{1}$ Department of Chemistry, Saurashtra University, Rajkot 360005, India \\ ${ }^{2}$ Department of Bioscience, Saurashtra University, Rajkot 360005, India \\ *E-mail address: shipra_baluja@rediffmail.com
}

\begin{abstract}
Some new dihydropyrano[c]chromenes derivatives are synthesized from 4-hydroxycoumarin. The structure of newly synthesized compounds was confirmed by mass, ${ }^{1} \mathrm{H}$ NMR and IR spectroscopy. Further, antimicrobial screening of these synthesized compounds was done against some bacterial (Gram positive as well as Gram negative) and fungal strains in N,Ndimethylformamide. It is observed that some of synthesized compounds exhibited significant antibacterial activity against Gram positive bacterial strains. The selected fungal strains were most resistant for the studied compounds as none of the synthesized compounds showed activity against any of the fungal strain studied. The best antibacterial activity was shown by ABR-10.
\end{abstract}

Keywords: Dihydropyrano[c]chromenes; Antibacterial activity; Gram positive bacteria; Gram negative bacteria; N,N-Dimethylformamide

\section{INTRODUCTION}

Coumarin constitutes one of the major classes of naturally occurring compounds and interest in its chemistry continues unabated because of its usefulness as biologically active agents. It also represents the core structure of several molecules of pharmaceutical importance. This class of compounds are known to exhibit a wide spectrum of biological activities such as antioxidant [1-2], anti-inflammatory [3-4], anticoagulant [4], antibacterial [5-6], antitumour [7-8], etc. These pharmacological properties aroused our interest in synthesizing some new coumarin derivatives with the aim of testing their microbial efficacy.

Thus, in the present work, some new dihydropyrano[c]chromenes are synthesized. The structure of newly synthesized compounds was confirmed by mass, $1 \mathrm{H}$ NMR and IR spectroscopy. Further, antimicrobial screening of these synthesized compounds was done against some bacterial (Gram positive as well as Gram negative) and fungal strains in N,Ndimethylformamide (DMF). 


\section{EXPERIMENTAL}

\section{1. Materials}

Reagent grade chemicals were used without further purification. The purity of the synthesized compounds was checked by Thin Layer Chromatography.

\section{Synthesis of 2-(benzo[d]thiazol-2-yl)acetonitrile}

In an equimolar solution of 2-aminothiophenol and malano nitrile in ethanol, $0.5 \mathrm{ml}$ glacial acetic acid was added drop wise. The solution was stirred for $30 \mathrm{~min}$. Light yellow colored solid was formed which was filtered and dried.

\section{Synthesis of dihydropyrano[c]chromene derivatives}

In an equimolar methanolic solution of 2-(benzo[d]thiazol-2-yl)acetonitrile and 4hydroxycoumarin, different substitutes aldehydes were added in the presence of piperidine as a catalyst. The reaction mixture was refluxed for 8-9 hours. The product was filtered and recrystallized with ethanol.

Step-1.

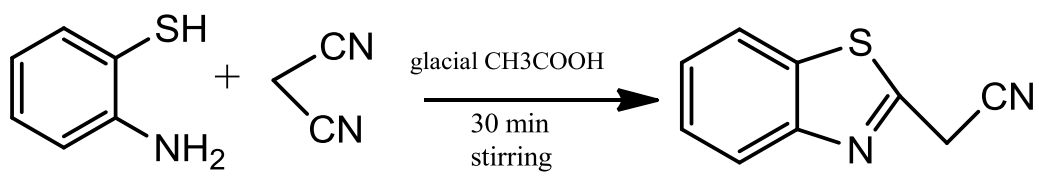

Step-2

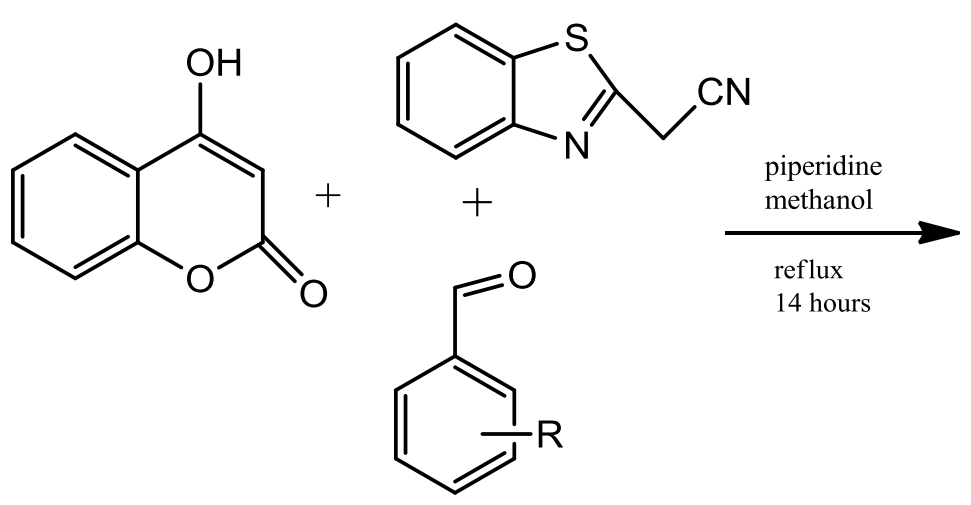<smiles>[R]c1ccc(C2C(c3nc4ccccc4s3)=C(N)Oc3c2c(=O)oc2ccccc32)cc1</smiles>

ABR-1to10

The physical constants of synthesized compounds (ABR-1 to ABR-10) are given in Table 1. IR spectra were recorded by SHIMADZU-FTIR-8400 spectrophotometer in frequency range of $4000-400 \mathrm{~cm}^{-1}$ by $\mathrm{KBr}$ powder method.

${ }^{1} \mathrm{H}$ NMR spectra were recorded by BRUCKER spectrometer (400 MHZ) using internal refences TMS and DMSO - d6. The Mass spectra were recorded by GCMS- SHIMADZUQP 2010. 


\section{ANTIMICROBIAL ACTIVITY}

\section{1. Microorganisms tested}

The studied microorganisms were obtained from National Chemical Laboratory (NCL), Pune, India. The microorganisms were maintained at $4{ }^{\circ} \mathrm{C}$. The Gram positive bacteria studied were Staphylococcus aureus ATCC29737 (SA), Corynebacterium rubrum ATCC14898 (CR), Listeria monocytogenes ATCC19112 (LM), Bacillus cereus ATCC11778 (BC); Gram negative bacteria were Pseudomonas aeruginosa ATCC27853 (PA), Escherichia coli NCIM2931 (EC), Klebsiella pneumoniae NCIM2719 (KP), Salmonella typhimurium ATCC23564 (ST) and Fungi were Candida albicans ATCC2091 (CA), Cryptococcus neoformans NCIM3542 (CN), Candida glabrata NCIM3448 (CG), Candida epicola NCIM3367 (CE).

The organisms were maintained on nutrient agar and MGYP medium (Hi Media, India) for bacteria and fungi respectively, at $4{ }^{\circ} \mathrm{C}$ and sub-cultured before use. The microorganisms studied are clinically important ones causing several infections and food spoilage.

\section{2. Agar well diffusion method}

In vitro antimicrobial activity of the new dihydropyrano[c]chromenes derivatives were studied against pathogenic microbial strains by the agar well diffusion method [9]. Mueller Hinton No. 2 / Sabouraud dextrose agar (Hi-media) was used for the antibacterial and antifungal susceptibility test respectively.

The new dihydropyrano[c]chromenes derivatives were dissolved in $100 \%$ DMF to give a concentration of $20 \mathrm{mg} \cdot \mathrm{ml}^{-1}$.

The Mueller Hinton agar / Sabouraud dextrose agar was melted and cooled to $48-50{ }^{\circ} \mathrm{C}$ and a standardized inoculum $(1.5 \times 108 \mathrm{CFU} / \mathrm{ml}, 0.5 \mathrm{McFarland})$ was then added aseptically to the molten agar and poured into sterile Petri dishes; wells $(8.5 \mathrm{~mm})$ were prepared in the seeded agar plates.

The test compound $(100 \mu \mathrm{l})$ was introduced into the well.

The plates were incubated overnight at $37{ }^{\circ} \mathrm{C}$ and $28{ }^{\circ} \mathrm{C}$ for $24 \mathrm{~h}$ and $48 \mathrm{~h}$ respectively, for bacteria and fungi. DMF were used as negative control. The microbial growth was determined by measuring the diameter of the zone of inhibition and the mean values are presented with \pm SEM.

\section{RESULTS AND DISCUSSION}

\section{1. Characterization}

IR, ${ }^{1} \mathrm{H}$ NMR and Mass spectral data of 2-amino-3-(benzo[d]thiazol-2-yl)-4-(3methoxyphenyl)pyrano[3,2-c]chromen-5(4H)-one (ABR-8)

IR: 3439.19 (N-H str.), $1746.60 \quad(\mathrm{C}=\mathrm{O}), 1306.82 \quad(\mathrm{C}-\mathrm{N}$ str.), 1271.13 (C-O-C str. assymetrical), 1114.89 (C-O-C str. sym.), 1586.50 ( $\mathrm{C}=\mathrm{C}$ str. aromatic), 3042.81 (C-H str. aromatic), ${ }^{1} \mathrm{H}$ NMR $(\delta \mathrm{ppm}): 3.698\left(3 \mathrm{H}, \mathrm{s},-\mathrm{OCH}_{3}\right), 4.766(1 \mathrm{H}, \mathrm{s},-\mathrm{CH}), 8.670\left(2 \mathrm{H}, \mathrm{s},-\mathrm{NH}_{2}\right)$, 6.755-8.670 (12H, multiplate, aromatic); Mass: (M/Z) 454, 410, 347, 291, 279, 265, 249, 174. 
Table 1. Physical constants of synthesized compounds.

\begin{tabular}{|c|c|c|c|c|c|}
\hline $\begin{array}{c}\text { Sr.No } \\
.\end{array}$ & $\begin{array}{c}\text { Compound } \\
\text { Code }\end{array}$ & $\mathrm{R}$ & $\mathrm{M} . \mathrm{F}$. & $\begin{array}{c}\text { M.W. } \\
(\mathrm{gm} / \mathrm{mol})\end{array}$ & $\%$ Yield \\
\hline 1 & ABR-1 & $-\mathrm{H}$ & $\mathrm{C}_{25} \mathrm{H}_{15} \mathrm{~N}_{2} \mathrm{O}_{3} \mathrm{~S}$ & 424 & 76 \\
\hline 2 & ABR-2 & $4-\mathrm{CH}_{3}$ & $\mathrm{C}_{26} \mathrm{H}_{15} \mathrm{~N}_{2} \mathrm{O}_{3} \mathrm{~S}$ & 438 & 73 \\
\hline 3 & ABR-3 & $3,4-\mathrm{di}-\mathrm{OCH}_{3}$ & $\mathrm{C}_{27} \mathrm{H}_{20} \mathrm{~N}_{2} \mathrm{O}_{5} \mathrm{~S}$ & 484 & 72 \\
\hline 4 & ABR-4 & $4-\mathrm{F}$ & $\mathrm{C}_{25} \mathrm{H}_{15} \mathrm{~N}_{2} \mathrm{O}_{3} \mathrm{SF}$ & 442 & 75 \\
\hline 5 & ABR-5 & $4-\mathrm{OCH}$ & $\mathrm{C}_{26} \mathrm{H}_{18} \mathrm{~N}_{2} \mathrm{O}_{4} \mathrm{~S}$ & 454 & 74 \\
\hline 6 & ABR-6 & $4-\mathrm{Br}$ & $\mathrm{C}_{25} \mathrm{H}_{15} \mathrm{~N}_{2} \mathrm{O}_{3} \mathrm{SBr}$ & 502 & 70 \\
\hline 7 & ABR-7 & $3-\mathrm{Br}$ & $\mathrm{C}_{25} \mathrm{H}_{15} \mathrm{~N}_{2} \mathrm{O}_{3} \mathrm{SBr}$ & 502 & 77 \\
\hline 8 & ABR-8 & $3-\mathrm{OCH}$ & $\mathrm{C}_{26} \mathrm{H}_{18} \mathrm{~N}_{2} \mathrm{O}_{4} \mathrm{~S}$ & 454 & 69 \\
\hline 9 & ABR-9 & $2,5-\mathrm{di}-\mathrm{OCH}{ }_{3}$ & $\mathrm{C}_{27} \mathrm{H}_{20} \mathrm{~N}_{2} \mathrm{O}_{5} \mathrm{~S}$ & 484 & 74 \\
\hline 10 & ABR-10 & $3-\mathrm{Cl}$ & $\mathrm{C}_{25} \mathrm{H}_{15} \mathrm{~N}_{2} \mathrm{O}_{3} \mathrm{SCl}$ & 453 & 73 \\
\hline
\end{tabular}

\section{2. Antimicrobial activity}

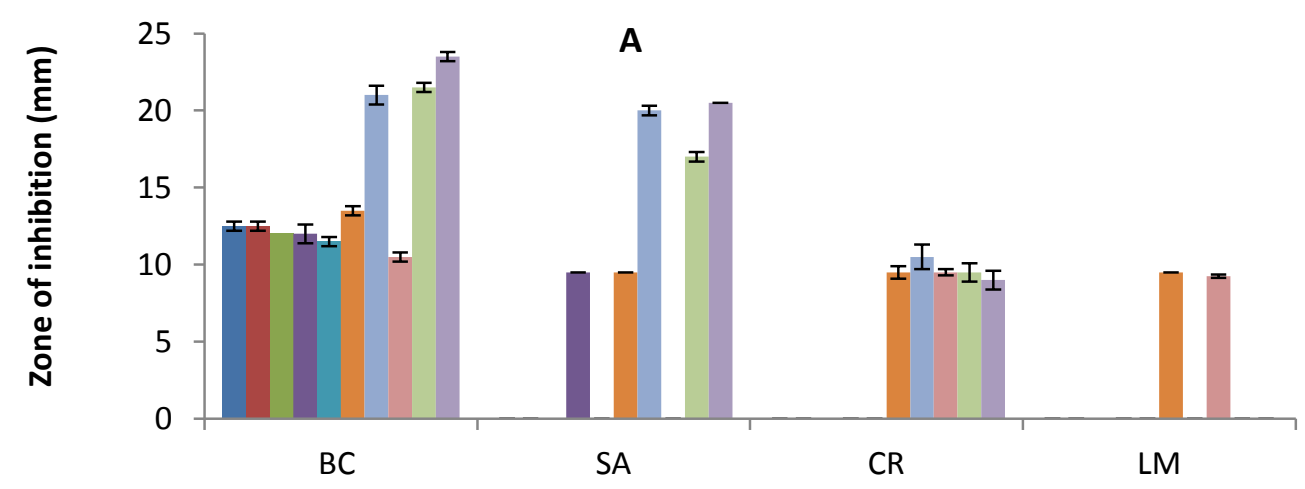

Gram positive bacteria

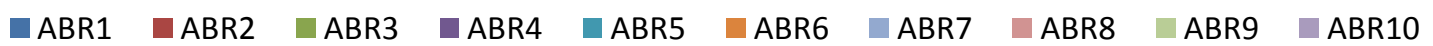

Fig. 1. Antibacterial activity of dihydropyrano[c]chromenes in DMF against (A) Gram positive and (B) Gram negative bacteria. 


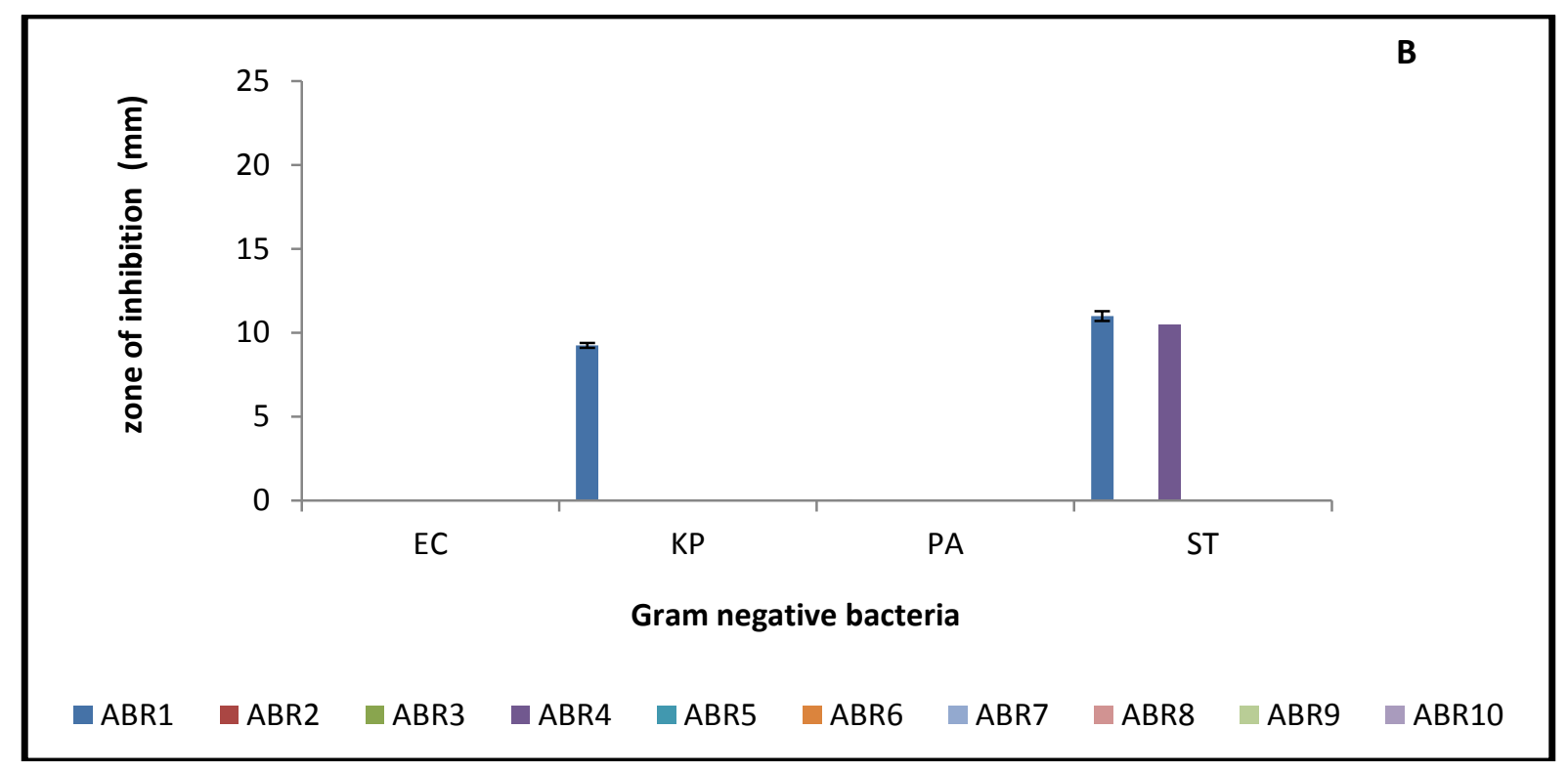

Fig. 1 (continue). Antibacterial activity of dihydropyrano[c]chromenes in DMF against (A) Gram positive and (B) Gram negative bacteria.

The 10 synthetic compounds and their respective controls produced different inhibition zones against the tested bacterial strains. The in vitro antibacterial activity of the ten compound in DMF against medically important Gram positive and Gram negative bacteria is shown in Fig. 1.

All the 10 compounds showed inhibitory activity against B. cereus but ABR-9 and ABR- 10 showed highest activity than all other strains studied. ABR-7, ABR9, ABR-10 showed higher activity than ABR-4 and ABR-6 against $S$. typhimurium. ABR-6, ABR-7, ABR-8, ABR-9, ABR- 10 showed lesser activity against $C$. rubrum, L. monocytogenes and $B$. cereus was the most susceptible bacteria, getting inhibited by all the 10 synthesized compounds.

None of the compounds in DMF showed antibacterial activity against $E$. coli and $P$. aeruginosa. ABR 1 showed some inhibitory activity against $K$. pneumonia compound and $S$. typhimurium. E. coli and $P$. aeruginosa were the most resistant bacterial strains not getting inhibited by any of the tested compounds. Different antibacterial activity with different side chains but same central moiety is already reported from work on Schiff bases from our group [10].

\section{CONCLUTION}

In the present study, the central moiety in all the compounds is dihydropyrano [c]chromenes with different side chains and because of this differential antibacterial activity was observed.

The best activity was with side chain 3-Cl (ABR-10). It can be concluded that different response of the synthesized compounds is because of their structural differences and the polarity of solvent used. 


\section{ACKNOWLEDGEMENT}

Authors are thankful to Department of Chemistry for providing laboratory facilities. The authors are also thankful for the facilities and grants given under UGC-SAP for Department Research Support (DRS) and Department of Science and Technology (DST) New Delhi for Fund for Improvement of Science and Technology (FIST).

\section{References}

[1] Trapkov VA, Parfenov EA, Smirnov LD. Pharm. Chem. J. 30 (1996) 445-447.

[2] Vukovic N, Sukdolak S, Solujic S, Niciforovic N. Arch. Pharm. Res. 33 (2010) 5-15.

[3] Emmanuel-Giota AA, Fylaktakidou KC, Hadjipavlou-Litina DJ, Litinas KE, Nicolaides DN., J. Heterocyclic Chem. 38 (2001) 717-722.

[4] Hamdi N, Dixneuf PH. Topics in Heterocyclic Chemistry, Springer-Verlag, BerlinHeidelberg, 2007.

[5] Basanagouda M, Kulkarni MV, Sharma D, Gupta VK, Sandhyarani P, Sasal VP. J. Chem. Sci. 121 (2009) 485-495.

[6] Liu X, Dong M, Chen X, Jiang M, Lv X, Zhou J., Appl Microbiol Biotechnol. 78 (2008) 241-247.

[7] Wang M, Wang L, Li Y, Li Q., Trans. Met. Chem. 26 (2001) 307-310.

[8] Marchenko MM, Kopyl'chuk GP, Shmarakov IA, Ketsa OV, Kushnir VN, Pharm. Chem. J. 40 (2006) 296-297.

[9] Perez C, Paul M, Bazerque P., Acta Biol Med Exp 15 (1990) 113-115.

[10] Baluja S, Parekh J, Chanda S, Vaishnani KP, J Indian Chem Soc 86 (2009) 1338-1342. 